\title{
Is poverty a matter of perspective? Significance of Amartya Sen for the church's response to poverty: A public practical theological reflection
}

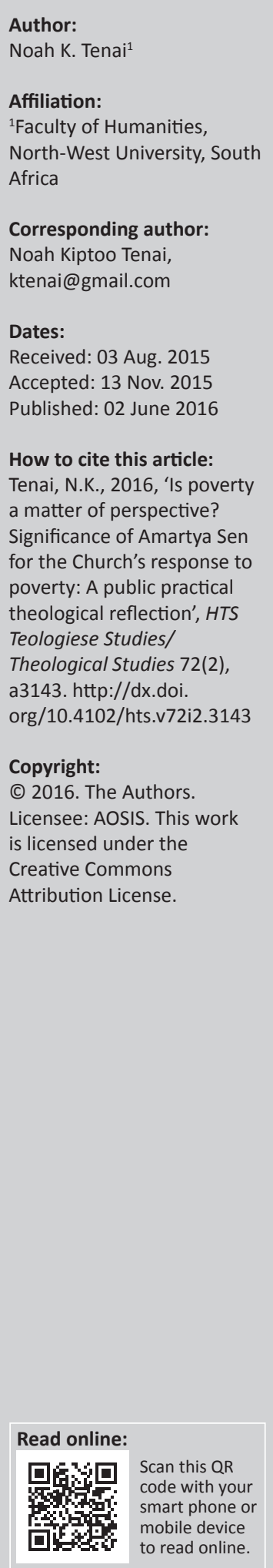

Poverty continues to present an enormous challenge to the well-being of humanity. Different frameworks on poverty tend to identify different persons as poor, impacting on efforts to fight poverty. The church as a role player in the public domain needs a framework that can assist it in its task of working for salvation and liberation in the face of overwhelming poverty. A combined framework, from Amartya Sen's entitlement approach and capability approach, is amalgamated and suggested as an integrated framework that could act as a lens or a viewpoint from which the church could venture to conceptualise, quantify and respond to instances of poverty.

\section{Introduction}

How do we construct a framework that ensures, in modern and postmodern pluralistic societies, that the church ${ }^{1}$ is assisted to address the challenge of poverty in the context of the global market economy?

In developing a framework that serves this aim, an attempt is made to learn some lessons from the works of Amartya Sen, with particular focus and attention to his entitlement approach and capability approach. Sen's entitlement approach and capability approach can assist in the reconstruction of a framework that can aid churches to engage more meaningfully and effectively in discourses that concern how poverty can be conceptualised, quantified and countered.

The article illuminates the potential of Sen's perspective on poverty that can enhance the calling of the church to attend to the plight of the poor. Sen's entitlement approach and capability approach are examined, with a view to suggest how such an endeavour could guide contemporary churches in their task of working for salvation and liberation in the face of overwhelming poverty.

\section{Poverty? What poverty? Asking and answering the question}

There is no consensus on how best to conceptualise, quantify and even respond to poverty. How poverty is defined and measured depends mainly on who is asking the question, how the question is understood, and ultimately, who responds to the question. ${ }^{2}$

Poverty (on account of its depriving, dehumanising and excluding characteristics) has to be fought. Fighting poverty has to be a central objective in any worthwhile development policy locally, nationally and globally.

There are various ways that have been used over time to conceptualise and quantify the reality of poverty. ${ }^{3}$ Each framework used to conceptualise and quantify poverty identifies different persons as being poor, with either positive or negative implications on any attempts to a response. 1.The concept 'church' is here used in terms of its various manifestations, that is, the church as 'a worship service, as local congregation,
as denomination, as ecumenical church, as individual Christians in their normal daily roles as family members, workers, participants in
culture and sport etc., and lastly church as individual Christians involved as volunteers in various institutions of civil society' (Koopman
2005:152).
2.In the introduction of a book that they co-edited, William A. Galson and Peter H. Hoffenberg observed that: 'On the conceptual level,
there remain disagreements about the precise working definition of poverty, a debate often focusing on whether a specific income
level defines poverty, whether it is better viewed in relative terms, or perhaps in noneconomic terms such as social exclusion or
deprivation capabilities' (Galston \& Hoffenberg 2010:2).
3.There are no attempts in this article to actually quantify poverty. There are no efforts made to get into discussions and debates that
concern the amount of poverty either locally of globally, including where that poverty is currently located. The existence of poverty (however conceptualised) is consciously and deliberately taken as a matter of fact. 
There are a myriad ways designed to fight poverty either through poverty reduction, poverty alleviation, or poverty eradication (Downs 2008:39-53; Graig \& Porter 2002:53-69; Hussain \& Hanjra 2004:1-15). The challenge that confronts each design is the question of what poverty is. A conceptualisation of poverty is crucial to its quantification and subsequent response(s).

There are various attempts made towards identification and quantification of poverty. However, each attempt immediately has to deal with some issues. It is discerned in Laderchi, Saith and Stewart (2006) that:

There are a number of issues involved in defining and measuring poverty. Is it confined to material aspects of life, or does it also include social, cultural and political aspects? Is it about what may be achieved, given the resources available and the prevailing environment, or what is actually achieved? Should definitions and measurement methods be applied in the same way in all countries and used for comparisons? Are there 'objective' methods, or are value judgments involved? What is the rationale for defining a poverty line? Should it be absolute as in the Millennium Development Goals and in most developing countries, or relative as in the rich OECD countries? ... Should poverty be defined and measured at the individual, household or geographic area level; and for what respective purpose? The multidimensionality issue considering that individual well-being/poverty manifests itself in multiple dimensions, should an aggregate index be developed, and how? Finally, the time horizon over which poverty is identified needs to be specified - many people move in and out of poverty over seasons and years, hence the longer the time perspective the less poverty will appear. (p. 10)

This demonstrates the kind of challenges that any attempt aimed at responding to poverty has to confront. Four approaches to conceptualisation and quantification of poverty that identify different people as being poor follow.

\section{A monetary approach (MA) to poverty}

This approach conceptualises poverty in terms of a shortfall on consumption or income on the basis of a poverty line. Imputation of monetary value is placed on subsistence production and social services and other public goods based on market prices (Laderchi et al. 2006:10). ${ }^{4}$

A relative poverty line is obtained by a political consensus, while an absolute poverty line is determined on the basis of an identification of behavioural breaks between those who are poor and those who are not - on account of nutritional needs for survival. There are merits to this approach. It has been discerned by Laderchi et al. (2006) that:

'Economic' measures of well-being are popular with policy makers because they are useful when they need to make quick, rough-and-ready, short-run, aggregate inferences in order to make an assessment. Such measures are more responsive, changing much faster than 'non-economic' social data, which

4.The basic needs approach to poverty can be traced to the contributions of Pau Streeten, Mahbub ul Haq, Javed Burki, and Francis Stewart, in the 1970s and 1980s eras, who worked at the World Bank (Streeten et al. 1982). Poverty from an inequality perspective was initially advanced by Miller et al. (1967), and Wedderburn (1974). suffer a time lag. They are more likely to be ... available than 'non-economic' measures, and are also cheaper and less complex to collect than are 'non-economic' poverty data. (p. 10)

A monetary approach has the appearance of a rigorous, simple, direct, measurable and seemingly unambiguous slant. Needless to say that this approach is based on tangible phenomena, that accommodate quantification such as income or expenditure and are seemingly more objective (in the sense that it can apply to all) than subjective (i.e. health and education may differ from person to person) (Sumner 2007:8).

Conceptualisation of poverty from a monetary perspective continues to have a preferred status compared to nonmonetary perspectives, not only for technical reasons but also because of its supposed objectivity on account of assumptions about its tangible, quantifiable and universal nature. Limitations to this approach are noted in Laderchi et al. (2006) that:

[T]here are problems about nutritionally based poverty lines. Differing metabolic rates, activities, size, gender and age among people mean that what is adequate varies among them.... Moreover, poverty lines are often drawn up at the level of the household, disregarding how the intra-household distribution affects individual nutrition levels. (p. 10)

Sakiko Fakuda-Parr (2010:16) observes that the limitations of the monetary approach to understanding and measuring poverty are stirringly evident. She notes that, poverty is in itself very complex and amorphous, as such; the perspective seems to neglect and/or ignore other factors that contribute to explaining, shaping, and driving poverty trends. It fails to factor in lived experiences and non-income, social and political aspects of poverty. Some non-monetary indicators for well-being that may play a role in poverty situations as reflected in the Millennium Development Goals (2008:1-2), include: education (i.e. enrolment rates, literacy rates, and survival to the final grade of primary or secondary school, or completion of primary or secondary school), health and nutrition (i.e. malnutrition rates, mortality and morbidity rates, life expectancy, infection rates, health service usage, e.g. skilled personnel at birth, contraceptive prevalence rate and immunisation rates), and environment (i.e. access to safe and healthy water sources, access to adequate sanitation and household infrastructure, e.g. permanent material used for walls of home, electricity supply, etc.).

Even with no consensus on how to define and measure poverty, Fakuda-Parr (2010:18) rightly observes that there is a broad recognition that the income perspective is too narrow to capture the complexity of poverty as a life experience of people.

A monetary approach to poverty identifies those who live below the poverty line as poor.

\section{A social exclusion (SE) approach to poverty}

Social exclusion implies marginalisation and relegation away from the main social arrangements within a given community, 
including its entitlements and opportunities, ordinarily as a consequence of poverty or on account of being an insignificant other.

The effectiveness of social exclusion as a concept is the support that it lends to the importance of social relationships, especially in resource distribution, control and usage. The concept suggests exclusion of sorts from decision-making, social services, including community and family support (Adato, Carter \& May 2006:229). A social exclusion approach to poverty, according to Laderchi et al. (2006; see also Runciman 1966; Townsend 1971) therefore:

[L]ends itself to the study of structural characteristics of society and the situation of marginalised groups ... leads to a focus on distributional issues - the situation of those deprived relative to the norm generally cannot improve without some redistribution of opportunities and outcomes. (p. 11)

A social exclusion approach to poverty sheds light to marginalisation and multiple faces of deprivation. It allows for an analysis on the dynamics and processes that breed and sustain deprivation. Social exclusion implies the exclusion to the rights of citizenship. It is directly interconnected with the existence of discriminatory forces, such as racism, and the outcome of market failures and unenforced rights.

The approach allows for a study of 'structural characteristics' of a society, including conditions of marginalised peoples, such as the landless and ethnic minorities. As such, attention is directed to 'distributional issues'. Distribution of opportunities and outcomes becomes crucial on account of awareness that the poor and deprived people may not be able to improve their circumstances in and of themselves. In situations of exclusion, there are 'excluders' and the 'excludees'. The approach attempts to identify these role players (Laderchi et al. 2006:11).

A social exclusion approach to poverty has its weaknesses. It is further acknowledged in Laderchi, Saith and Stewart (2003), that it is difficult:

[T]o identify appropriate norms to provide the benchmarks of exclusion, since exclusion from formal sector employment or social insurance coverage tends to apply to the majority of the population. ... To the extent that the normal may not be desirable, what is 'normal' may not be satisfactory in defining the benchmarks of exclusion. Consequently, there is a serious problem in deciding what would be appropriate [social exclusion] characteristics. A further complication is that exclusion, as with the caste system, is part of the social system in some societies. (p. 259)

Some people in a community who appear 'included' may in other ways feel excluded. Certainly, failure to possess what the community values or appears to value (even for the wrong reasons) is still a form of exclusion.

Shame is used (by various marketing companies) to sell commodities, that is, from mobile phones to fashion labels. A sense of shame does function to persuade a target people to prioritise the opinions of others over their own:
[A]utonomous appreciation of usefulness, beauty, pleasure, sufficiency or desire, and thus to censor those needs which, by their singularity - or, for that matter, their conviviality - do not correspond to commodified products. (Bowring 2000:315)

Advertising companies can purposely, shrewdly and suggestively market products by infusing a sense of pride, honour and glory to those who purchase or consume their products, and impress a sense of shame and humiliation on those who do not. So, those who choose not to purchase or consume those products are 'othered' (socially excluded). Even teenagers, whose parents may not allow them to own some products, because they may have wanted those products for the wrong reasons, may see themselves as socially excluded among their peers, and develop a sense of humiliation, shame and embarrassment.

An apparent weakness to the SE approach is the lack of a clear distinction between induced social exclusion (i.e. through marketing, purchase and consumption of some products) and other forms of social exclusion so fare referred to.

A social exclusion approach to poverty distinguishes those who are marginalised and powerless (socially excluded) as living in poverty.

\section{Participatory approach (PA) to poverty}

A participatory approach to poverty anticipates a dominant role being played by the people themselves regarding assessments on what it means to be poor and the scale of poverty (Chambers 1994, 1997). The Participatory Poverty Assessment (PPA) developed out of participatory rural appraisal (PRA), 'to enable local people to share, enhance and analyse their knowledge of life and conditions, to plan and to act' (Chambers 1994:957).

A participatory approach to poverty arises from and emphasises poor people's ability and capacity to understand and analyse their own experiences and realities. The approach employs a rather flexible framework and methodology. Therefore:

[A] range of tools have been devised, including the use of participatory mapping and modelling, seasonal calendars, wealth and well-being ranking. The large variety of methods can be used flexibly. (Laderchi et al. 2003:261)

The approach presents a superficial appearance that everyone who has a stake, has a voice and a choice. It must, however, be noted that any so-called community-driven participatory planning, including other initiatives that make claims of full participation and empowerment can turn out to be driven by certain interests (i.e. racial, gender, class, ability, age, etc.) leaving the least powerful without a voice or much in the way of choice.

It has been observed that in some instances, women may not be able to fully, freely and equally participate like other 
members of a community, with regard to issues of poverty and development. Cornwall (2003) notes that:

The question of who participates and who benefits raises awkward questions for participatory development. The very projects that appear so transformative can turn out to be supportive of a status quo that is highly inequitable for women. (p. 1329)

What is true of women, may apply to people of colour, aged, young, physically challenged and those who openly claim alternative sexual orientations.

Without determinations integrated into a participatory approach to enable peripheral and marginal voices to be raised and heard, any assertions to inclusiveness made on behalf of participatory approach will appear rather hollow. Ensuring that the poor are consulted is essential and necessary, but insufficient and inadequate. Also, in instances of a participatory arrangement, working with differences that transpire in such situations, requires various skills that may not be present or have been disregarded. It may require updated skills with regard to issues that concern disagreement, conflict resolution, boldness and assertiveness, for example. The approach does not declare what poverty is or who the poor are, since such task is left to 'the people' to determine.

\section{Some preliminary observations}

Each approach (i.e. MA, SE, and PA) arises from a distinctive outlook on what represents a good life and what a virtuous people look like. Each approach demands practical postulations that are often not apparent in order to conceptualise poverty.

On account of the varied dissimilarities in characterisation of what counts as poverty, the people who are seen as poor tend to differ consistently to the approach and the particular processes engaged in each respective approach and each approach would have different implications on a response to poverty.

The MA proposes a solution to poverty that revolves around a generation of economic or financial incomes. It intimates emphasis on growing cash incomes through economic growth, or redistribution. Responding to poverty is about growing production and consequently money incomes for the poor and deprived.

The SE has an awareness implied regarding the inability of economic growth alone to once-and-for-all eradicate social exclusion. The approach gives significance to redistributive measures, and prioritises correction of discrimination of any sorts, including fighting class barriers, or citizenship restrictions. The approach highlights the need to disrupt exclusionary elements.

The PA prioritises and attends to collective (group) characteristics.
On account of the apparent non-existence of correspondence between the different approaches so far discussed, using one approach, in exclusion of the other, comes with serious errors. What framework, therefore, reflects a concern for a broader characterisation of poverty being constructed in order to aid the fight against poverty?

\section{An open tête-à-tête with Amartya Sen: Entitlement and capability approaches}

Sen advances what can be very helpful models to any efforts aimed at an identification, conceptualisation, quantification and countering of situations of poverty. Sen does so in his two approaches, namely, the entitlement approach and capability approach.

Sen is a Thomas W. Lemont University Professor and Professor of Economics and Philosophy at Harvard University. His 2013 curriculum vitae notes that he was a senior fellow at Harvard Society of Fellows and a formerly Master, Trinity College at Cambridge (England), during the period 1998-2003. He is of Indian decent, born on 03 November 1933 in Santiniketan, India. He obtained a BA degree in 1953 through Presidency College, Calcutta, and another BA degree through Trinity College, Cambridge in 1955, and a PhD in 1959. He has obtained a myriad of professional elections and awards right from 1984-2012 and has published close to 30 books. ${ }^{5}$ His first book was Choice of techniques (1960), and his latest is Peace and democratic society (2011). His published articles are categorised into 20 major areas (Harvard University n.d.:1 of 1; Harvard University 2013:1-30). Sen dedicates his books and articles to the phenomenon of poverty. His interest in alternative poverty measures began in the late 1950s at the University of Cambridge when he began discussing an alternative to the Gross Domestic Product (GDP) per capita benchmark. He is known to have pointed out that: 'This dollar-a-day measure doesn't take into account many variations that influence the conversion of income into good living' (Morrell 2011:1 of 1).

\section{Sen's entitlement approach}

Sen's entitlement approach sheds light to possible and legitimate rights of ownership within a community on the basis of entitlement relations. Exchange entitlements within the realm of exchange relations envisage the ability to (legitimately, fairly and freely) exchange what one owns for another set of commodities. Poverty arises when there is a decline in one's exchange entitlements (i.e. when, what one owns, no longer guarantees access to what could have been previously obtained through exchange), and not so much due to a decline in commodity supply. Therefore, poverty is more about inaccessibility and less about unavailability.

Sen's entitlement approach is very helpful in engaging instances of poverty. Entitlements refer to establishment of command

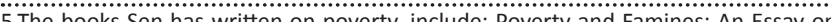
(1981), Commodities and Capabilities (1985), The Entitlement and Deprivation (1981), Commodities and Capabilities (1985), The Standard of Living (1987), Hunger and Public Action (1989), The Political Economy of Hunger, in 3 volumes (1990 \& 1991), Inequality Re-examined ([1992] 2000), Handbook of Social Choice and Welfare: Volume II (2011). 
'over some alternative commodity bundles' within a social structure, 'given the prevailing legal, political, and economic arrangements'. So a set 'of alternative bundle of commodities over which a person can establish ... command will be referred to as this person's “entitlements"' (Drèze \& Sen 1989:9).

The approach sheds light on possible and legitimate rights of ownership within a particular community. Sen (1981) includes the following into his list of entitlement relations, namely:

- Trade-based entitlement: One is entitled to own what one obtains by trading something one owns with a willing party or set of parties.

- Production-based entitlement: One is entitled to own what one gets by arranging production using one's owned resources.

- Own-labour entitlement: One is entitled to one's own labour power, and thus to the trade-based and productionbased entitlements related to one's labour power.

- Inheritance and transfer entitlements: One is entitled to own what is willingly given by another who legitimately owns it (pp. 2-3).

According to Sen (1981:3), a person can exchange what he or she owns for another collection of commodities through 'trading, or through production, or through a combination of the two'. Therefore, 'exchange entitlement' implies 'the set of all the alternative bundles of commodities that he can acquire in exchange for what he owns'. The use of 'exchange entitlements' (Drèze \& Sen 1989:23) refers to 'a "mapping," specifying for each endowment bundle a set of alternative commodity bundles any one of which a person can use to acquire'.

The approach is essentially about endowment and entitlement sets. Attention is drawn to the existence of an endowment set that involves ownership that is consistent with conventional rules and practices within a community, including an acknowledgment of ownership of property and ownership of talents and abilities, expertise, labour power, and a belonging to one's community. Attention is also drawn to an entitlement set, which is about an amalgamation of all the conceivable commodities and services that one can legitimately and rightfully acquire, using the resources of one's endowment set. Attention is equally drawn towards an exchange entitlement or entitlement mapping, which is about a relationship between the endowment set and entitlement set. Exchange entitlement or entitlement mapping responds to the question of the rate at which available possessions of the endowment set can be converted into commodities and services involved in the entitlement set.

One may be exposed to famine, for example, 'if for the ownership that [one] actually has, the exchange entitlement set does not contain any feasible bundle' which could be exchanged or traded for what one needs or does not own. So, a person's ability to avoid poverty 'would depend both on [one's] ownership and on the exchange entitlement mapping that [one] faces' (Sen 1981:14).
This approach can help us to approach and conceptualise poverty from a perspective of a decline in one's exchange entitlements. The implication is that one's exchange entitlements may worsen and be exposed to various forms and levels of poverty for reasons other than a general decline of commodity supply (Sen 1981:4). Sen is here saying that poverty is not so much a problem of unavailability, but inaccessibility! Inaccessibility occurs when entitlements are infringed upon and dismantled.

In view of the foregone discussion, Sen (1981:156) advances that in analysing poverty, classifying a population into the rich and the poor is unhelpful because such an approach is too undiscriminating. ${ }^{6}$ The category of the poor, as Sen (1981:157) asserts, is not only inadequate for evaluative exercises, but also has 'distorting effects on policy matters'. The lack of discrimination between different circumstances leading to poverty, leads to a lack of focus in policy choice. ${ }^{7}$

Strategies for entitlement protection are suggested. Such strategies include:

- Non-exclusion, targeting and selection (Drèze \& Sen 1989: 104-106).

This involves a direct and unconditional protection of all the entitlements of everyone. A selection procedure ${ }^{8}$ must be adopted to determine the eligibility of different groups of people to public support.

\section{- Alternative selection mechanisms (Drèze \& Sen 1989:107-109).}

This entails three selections, that is administrative selection (based on observable indicators of deprivation and/or need such as status, asset ownership, demographic characteristics, or geographical location); market selection (intervening impersonally at the level of the market to either subsidise or support prices); self-selection (self-acting tests, e.g. requiring work in exchange for relief, in order to discourage privileged groups).

- Feeding and family (Drèze \& Sen 1989:109-113).

In crisis situations where extensive signs of enhanced deprivation and/or undernourishment are visible, allocation of relief on the basis of observed nutritional status becomes a selection mechanism option. This option is helpful in the identification of vulnerable individuals rather than households for purposes of direct feeding and/or assistance.

\footnotetext{
6.Sen however acknowledges that such classification may serve some other purpose(s) in other contexts. Sen (1981:156) argues that the entitlement approach
'requires the use of categories based on certain types of discrimination'. The logic of 'requires the use of categories based on certain types of discrimination'. The logic of the entitlement approach draws from the tradition on Karl Marx who emphasised
the importance of 'analysing economic movements through disaggregation the importance of 'analysing economic movements through disaggregation taking a more disaggregative view of the economy than one might get from standard class analysis. The entitlement approach's rejection of categorisation of humanity as either rich or poor, demands 'much greater refinement of categories to be able to characterize entitlements of different groups, with each group putting togethe different people who have similar endowments and entitlements' (Sen 1981:156).

7.For further reading on some evidence that gross characterisation of poverty leads to distortions of public policy, see Appendix A, in Sen's, 1975 book, entitled Employment, Technology and Development.

8.The amount of distress experienced by individuals is common knowledge within a given community. As such, the selection process has to rely on local institutions 'to allocate public support according to individual needs' (Drèze \& Sen 1989:107).
} 


\section{- Employment and entitlement (Drèze \& Sen 1989:113-118).}

This entails the provision of employment for generating compensating income.

Some limitations to Sen's entitlement approach have been noted (Sen 1981:48-50). ${ }^{9}$ There is failure in the approach to plainly and coherently present specifications regarding what entitlement is. The notion of entitlements is not clearly defined. The approach also gives little attention to instances where there is transfer of ownership through violent means, that is, looting and loss of ownership on the grounds of, for example, people's habits, apathy, or ignorance. There is also a failure within the approach to situate the human person as located within a nation state, a community and a family. Situating the person within the nation, community and family is key in establishing and protecting any entitlements of any sorts (Devereux 2001:259). There is also failure to recognise that poverty can be a result of 'political crises as much as they are economic shocks or natural disasters' (Devereux 2001:259). ${ }^{10}$

From the perspective of Sen's entitlement approach, poverty manifests within circumstances where entitlements are infringed upon and dismantled. The general challenge of entitlement protection is a multifaceted one that carries with it a network of diverse policy areas. It includes a refinement of categories of people in order to be able to characterise, nurture and protect their entitlements. Entitlement protection calls for mixed systems that involve the use of diverse instruments for the provision of either direct or indirect support for all vulnerable people groups.

\section{Sen's capability approach}

Sen's capability approach perceives life as fuller and richer if it offers genuine choices with alternatives. It sees the quality of life in terms of the ability to achieve various combinations of functionings, in terms of what one has reason to value. It gives deliberate attention to the individual person as the basis of capability assessment.

For Sen (2009:19) 'capability is the power to do something' and 'the accountability that emanates from that ability ... is a part of the capability perspective'. ${ }^{11}$ It is 'the freedom that

9.Some of the limitations put forth by Sen $(1981: 48-50)$ include that, One: 'There can be ambiguities in the specification of entitlements, entitlements may not be well defined'. Two: 'while entitlement relations concentrate on rights within the given defined. Two: 'while entitlement relations concentrate on rights within the given legal structure in that society, some transfers involve violation of those rights, such as looting or brigandage'. Three: 'people's actual food consumption' or commodity consumption, may fall below their entitlements for a variety of other reasons, such as ignorance, fixed food habits, or apathy'. Four: The entitlement approach focuse on starvation, which has to be distinguished from famine mortality, since many of the famine deaths - in some cases most of them - are caused by epidemics, which have patterns of their own'

10.Failure to see famine as such, '[Results in] an elegant analytical framework that privileges the economic aspects of famine and excludes the social and the political: the importance of institutions in determining entitlements (at intrahousehold or community level), famine as a social process (mortality due to communicable diseases) and violations of entitlement rules by others (complex emergencies). Without a complementary social and political analysis, the entitlement approach can illuminate only a small part of a very complex phenomenon' (Devereux 2001:259).

11.Capabilities are attributes of people, not of collectives, such as communities. Sen (2009:247) maintains that individual human beings have various plural identities, multiple affiliations and diverse associations. Individuals are social creatures with different types of societal interactions. As such, Sen is against any proposals to see a different types of societal interactions. As such, Sen is against any proposals to see a
person merely as a member of one social group. To Sen, such a perspective is based on an inadequate understanding of the breath and complexity of any society on earth. people have in pursuing valuable activities or functionings' (Drèze \& Sen 1989:42).

There are two expressions of capabilities. The one expression is elementary capabilities, involving 'the ability to avoid undernourishment and related morbidity and mortality'. The other involves social capabilities 'such as taking part in the life of the community and achieving self-respect' (Drèze \& Sen 1989:12).

Sen (1992:39-42) uses the capability perspective to assess well-being ${ }^{12}$ and the freedom to pursue well-being. He argues that one's capabilities are a combination of functionings, that is, beings and doings that a person can achieve. Capability is 'a set of vectors of functionings, reflecting the person's freedom to lead one type of life or another' (Sen 1992:40).

A person's well-being is linked, as Sen (1992:40-42) agues, to his or her capabilities. The capability to achieve all the alternative combinations of functions a person can choose to have, constitutes that person's freedom (the real opportunities) to have well-being. This kind of well-being freedom has implications in ethical and political analysis (Sen 1992:40). ${ }^{13}$ Also, 'achieved well-being is dependent on the capability to function' (Sen 1992:41). This means that choosing is central to living and a life that offers authentic choices with alternatives is fuller and richer.

Sen (2009:232-235) advances specific features for the capability approach. He maintains that - Firstly: The capability approach points to an informational focus in judging and comparing overall individual advantages, and does not, on its own, propose any specific formula about how that information may be used. The capability approach focuses on information on individual advantages judged in terms of opportunity. It draws attention to the relevance of the inequality of capabilities in the assessment of social disparities, without suggesting any specific formula for policy decisions (Sen 2009:232). Secondly: The capability perspective is concerned with a plurality of different features of our lives and concerns. It is concerned with one's ability 'to achieve various combinations of functionings' which one can compare and judge against others in terms of what one has reason to value. It is focused on human life and not just on incomes or commodities that one may be in possession of. ${ }^{14}$ It is a departure from a concentration on 'the means of living to the actual opportunities of living' (Sen 2009:233).

\footnotetext{
12.Sen (1992:39) uses well-being to represent the quality or welliness of a person's being. For Sen, living could be seen to be consisting of what he calls 'a set of interrelated "functionings," consisting of beings and doings'. An evaluation of a person's well-being has to therefore take into consideration an assessment of those functionings.

13.In policy discussions, emphasis may be placed on the freedoms that different people respectively enjoy to achieve well-being (Sen 1992:40).

14.Sen (2009:234) expands this point further by giving a very helpful example. He writes: ' $[I]$ f a person has a high income but is also very prone to persistent illness, .. then the person need not necessarily be seen as being very advantaged, on the mere ground that her income is high. She certainly has one of the means of living well ... but she faces difficulty in translating that into good living ... because of the adversities of illness and physical handicap. We have to look instead at the extent adversities of illness and physical handicap. We have to look instead at the extent
to which she can actually achieve, if she so chooses, a state of good heath and wellness, and being fit enough to do what she has reason to value.'
} 
Sen's capability approach adds value to an analysis of public action against poverty by expanding attention from means (command over commodities, income, food, etc.) to the actual human life as it can be lived. The approach calls for the prevention of deprivation of basic capabilities. The approach calls for an expansion of choices and capabilities so that people may lead the kind of lives they value.

Sen's capability approach assesses poverty beyond the income method. ${ }^{15}$ Sen (2009:254) contends that much as there may be some merit in assessing the presence or absence of poverty from a presence or lack of an income and/or primary goods, it has to be acknowledged that 'different people can have quite different opportunities for converting income and other primary goods into characteristics of good living and into the kind of freedom valued in human life'. ${ }^{16}$

Poverty is capability deprivation (Sen 1989:41-45, 2009: 254-257). It is as a result of failure of basic capabilities that are critical to a person's well-being. The approach links 'poverty to the failure of the ability to achieve precisely those things that are ultimately important' (1989:45). A response to poverty then (see Sen 1984, 1989, 1999), is about the expansion of choices and capabilities that people can have in order to lead lives they value.

The focus of the capability approach is on what a person actually ends up doing, and also on what he or she is in fact able to do, whether or not he or she chooses to make use of that opportunity (Sen 2009:235ff.).

The capability approach has its limitations. Sen (2009: 295-298) discusses four main limitations of the capability approach, particularly in relation to equality and other concerns, namely:

1. '[C]apability is ... only one aspect of freedom, related to substantive opportunities, and it cannot pay adequate attention to fairness and equity involved in procedures that have relevance to the idea of justice (Sen 2009:295)

2. '[T]here can be other demands on distributional judgments, which may not be seen as demands for equal overall freedom for different people, in any clear sense' (Sen 2009:297)

3. '[C]apability does not speak in one voice, since it can be defined in different ways, which include the distinction between well-being freedom and agency freedom' (Sen 2009:297)

15.There is an obvious acknowledgement of poverty in terms of low income; however the inadequacy of such an approach is recognised. The capability approach goes beyond an evaluation of people's circumstances only on the basis of variables such as (primary and/or basic) goods, resources, or even actual income. These variable are seen as means to freedom. The question that the capability approach raises is whether one has the freedom to pursue these elements to attain well-bein (Sen 1992:42). Primary goods according to Sen (1992:81) include income, wealth, et cetera.

16.Sen (2009:225-226) discusses various types of contingencies that bring about variations in conversion of income into the kinds of lives that people can lead. He (2) diversities in the physical environment, (3) variation in social climate, and (4) differences in relational perspectives. Sen does this to show that real poverty, especially in terms of capability deprivation, is much more intense than can be
end deduced from income data.
4. '[E]quality is itself not the only value with which a theory of justice can be concerned, and it is not even the only subject for which the idea of capability is useful' (Sen 2009:298).

\section{The entitlement and the capability approaches combined and integrated}

It is helpful to link Sen's two approaches together (entitlement approach and capability approach) and view each as a portion of the other, so that the two make one larger approach. Each approach could be seen as representing one of the wheels of a bicycle, with each complementing the other, by highlighting a rather composite framework to a conceptualisation, quantification and response to poverty. Such a view is helpful especially in the light of possible apparent deficiencies inherent in each approach.

As the one wheel of the bicycle, Sen's entitlement approach is an argument about 'distributional efficacy'. The entitlement approach 'gives us a perspective that focuses on the 'distributional efficiency' of an economy, that is, on its real capacity to bring wealth to its citizens' (Sohlberg 2006:362). Poverty does not occur as a direct result of a shortage of supply. It is really a question of insufficiency of entitlements, when entitlements are infringed and dismantled. It is about commodity accessibility vis-à-vis unavailability. It is helpful to locate Sen's entitlement approach within his large conversation, which includes the capability approach.

As the other wheel of the bicycle, the capability approach has an emphasis on functionings (various mechanisms of how a person lives). The approach highlights the centrality of freedom as a valued capability. It is important for a people to have freedom - freedom to make their own choices whether those choices are right or wrong. The perspective stresses that how a people live should be regarded as more important than what they earn. It broadens an economy beyond mere commodities. The capability approach brings with it the language of understanding, compassion, commitment and quality of life. It's emphasis is on the human person, as the basis of human development and well-being assessment. This feature balances the entitlement approach where there is an apparent emphasis on the entitlement relation and not so much on the human person as situated within a larger community and state contexts. The capability approach emphasises public discussions; there is an advocacy for a decision procedure that establishes community priorities. This feature balances out the criticism that the entitlement approach fails to give attention to political crises and natural disasters. The capability approach envisions a situation where each community sets its own agenda in its own terms.

The substance of Sen's entitlement and capability wheels can enrich a reconstruction of a framework that can assist churches' response(s) to poverty. 


\section{Some good news to the poor? The church in Amartya Sen's company - A public practical theology engagement}

What are the implications of amalgamating Sen's approaches for the church? How may the church benefit from Sen, with regard to contributing to the fight against poverty so that the church becomes an authentic partner in the fight against poverty, and a bearer of good news to the poor? Sen's ideas and approaches provide a lens for a public practical theological approach. The approaches provide options and possibilities for theology to be practical within the public space. Practical theology involves a two-way movement between theory and practice (Klaasen 2014:1; Patton 1993:238). Browning (1985:16) added that a practical theologian should communicate with the church, but also with those outside of the church. Our interest here, however, is not to expend energy discussing the meaning of practical theology but to note that it is a theological approach that has two arms namely theory and practice and the individual 'that is the theologian' focuses on the church and outside the church.

When practical theology has its praxis outside the church it assumes a public theological role. According to Ganzevoort and Roeland (2014:91), praxis is the object of practical theology and that praxis in pluralistic, secularised and deinstitutionalised contexts should not be limited to explicitly religious or specifically Christian domains but include the broader field of spiritual and existential practices. Historically, three practical theological perspectives in studying lived religion have been distinguished: pastoral and/or ecclesial theology, empirical theology, and critical theology. In all three perspectives practical theology is a form of concerned engaged scholarship. Ganzevoort and Roeland (2014:91) observe that a pastoral and/or ecclesial approach to practical theology focuses on the church in ministries such as pastoral care while an empirical approach to practical theology tends to be aligned with the academic institutions. Practical theology as critical theology entails a public and contextual theology. Ganzevoort and Roeland (2014:91-97) explain that the history of practical theology as public and/or contextual theology includes liberation theology, feminist theology and similar currents of theological thinking that take a critical stance toward societal praxis and look for possible contributions from the religious tradition. This type of practical theology applies a hermeneutic of suspicion, builds on critical theory, allows for subjective voices of the marginalised, and aims at emancipation or liberation. Praxis here is the liberating effort to change society. From the above outline, practical theology takes a public practical theological role when it takes a critical and liberation theoretical stance. Therefore, this approach will be a lens that will be employed in our discussion.

\section{An amalgamation of Sen's approaches can enable the church to reflect more comprehensively on poverty by providing grounds for a broad based analysis and action}

The church's location within the community is critical to its role in accessing information necessary to any analysis of poverty. The church accesses a large body of information that if captured correctly, and accurately analysed, could yield very helpful lessons on how to identify, conceptualise, measure and respond to poverty.

The kind of testimonies, songs and poems composed by church members, the choice of hymns sung either at church or at the homes of church members, including the funerals, weddings and childbirths celebrations or lack thereof, can be a window to how well a people in the community are doing. Listening keenly and supplementing the listening with visitations to people's homes (and hospitals), as church ministers do, can offer opportunities where helpful information may be collected for analysis.

Actively listening to people's testimonies at church may draw attention to the kind of barriers that hinder them from accessing the kind of goods and services they require. Testimonies may, for example, indicate instances where a people are unable to convert their labour power (endowment sets) to good housing (entitlement sets).

Some information may be obtained by merely looking at what people look like as they come to church. How do they dress? Their choice of clothes, whether ironed or not, clean or not, their mien or demeanour, individual interactions, et cetera. The outside can offer clues to what could be going on in the inside of a person. The pain of poverty can be visible to the naked eye.

\section{An amalgamation of Sen's approaches can enable the church to reflect more comprehensively on the kinds of freedoms people have}

The church's message to the world is a message of freedom. It is a message of life in abundance (Jn 10:10; Lk 4:18-19). How does this message of freedom and life in abundance translate into a constructive fight against poverty? Sen draws the church's attention to the kind of choices people have. People who live life in abundance are people who have genuine options irrespective of whether they choose to make use of those options or not. The church's role becomes one of agitating for the creation of a society where people can genuinely choose.

An agitation for genuine options starts from within the church. The church has to start by eradicating any hindrances to the freedoms endowed by God to humanity. Barriers on the basis of gender, age, sexual orientation, race, class, ability, et cetera have to be eradicated. The church has to be a place where everyone is an equal member, enjoying all privileges of membership.

The church in Sen's company agitates against anything that negatively affects the option to live life in abundance and avoid poverty. Life snuffing elements include corruption, crime, wars, unemployment, exploitation of one by the other, human trafficking, substance abuse, consumerism, disease, 
famine, ignorance and so forth. Efforts directed to quantify such evils are central to ensuring that there is the creation of a completely free community of people who have genuine options.

The language of the church in Sen's company is one that employs within it such values as sympathy, commitment and quality of life. The church is in a better position to demonstrate what sympathy is. A people's quality of life can be enhanced through the development of a rapport with them coupled with a devoted dedication to their freedom and well-being.

\section{An amalgamation of Sen's approaches can enable the church to reflect more comprehensively on the kinds of decision-making processes}

What kinds of decision-making processes should be developed or enhanced, so that a people and communities make decisions consistent with their contexts, needs and aspirations?

Within a globalised context of a free market economy, and where multinationals tend to call the shots, some communities are manipulated and forced to change their livelihoods to suit the dictates of the powerful. Some communities are manipulated, by the promise of a better life, or even through the provision of skewed information sourced from sponsored research, to make decisions detrimental to their own existence.

The church in Sen's company allows for the empowerment of a people, as individuals and as communities, to establish priorities for themselves. The church becomes the watchdog that jealously guards the right for communities and peoples to exist in their uniqueness and to make decisions that help them enhance life within that community. It is important that each community sets its own agenda within their own terms.

\section{An amalgamation of Sen's approaches can enable the church to reflect more comprehensively on how to actively participate in the protection of a people's entitlements and capabilities}

A people can fully thrive within a context where their entitlements and capabilities are nurtured, developed and protected. The church is well located within the community to play a central role in the deliberate and targeted assistance provided for the most deprived.

The message and actions of the church have to be about ensuring that every individual can take part in the life of the community, with self-respect and freedom from shame, undernourishment, and related morbidity and mortality.

\section{Conclusion}

Pressure on governments is key to determining what actions are given priority by governments. A strategic approach on the part of the church, through public action, debates and discussions, can lead to, for example, early identification of threats to a people's entitlements that could lead to entitlement failure (poverty).

The church has to develop a perpetual culture of creative dissatisfaction in order to ensure the protection of a people's entitlements and capabilities. A people's capability to conquer poverty is really dependent on their command over commodities and their ability to use those commodities with skill. The church's public action directed, for example, to education, health, employment et cetera can contribute to that command and the necessary abilities.

The church has to build capacity, so that it is able to perpetually play an influencing role in social actions through either collaboration with the state or through an adversarial stance.

The state has a critical and central role to play in the fight against poverty. However, the role of the church has to go beyond the actions of the state to what the church itself does in the fight against poverty.

The public role of the church with regard to fighting poverty can be enhanced by a focused emphasis on Sen's amalgamated entitlement and capability approaches to poverty, with a view to promoting entitlements and expanding basic capabilities of people in communities.

\section{Acknowledgements Competing interests}

The author declares that he has no financial or personal relationships which may have inappropriately influenced him in writing this article.

\section{References}

Adato, M., Carter, M.R. \& May, J, 2006, 'Exploring poverty traps and social exclusion in South Africa using qualitative and quantitative data', Journal of Development Studies 42(2), 226-247.

Bowring, F., 2000, 'Social exclusion: Limitations of the debate', Critical Social Policy 20(3), 307-330.

Browning, D.S., 1985, 'Practical theology and political theology', Theology Today 42, 15-33.

Chambers, R., 1994, 'The origins and practice of PRA', World Development 22(7), 953969.

Chambers, R., 1997, Whose reality counts? Putting the first last, Intermediate Technology Publications, London.

Cornwall, A., 2003, 'Whose voices? Whose choices? Reflections on gender and participatory development', World Development 31(8), 1325-1342.

Devereux, S., 2001, 'Sen's entitlement approach: Critiques and counter-critiques', Oxford Development Studies 29(3), 245-263.

Downs, T.J., 2008, 'Transforming impact assessment for sustainable development and poverty eradication', Engineering Sustainability 161, 39-53.

Drèze, J. \& Sen, A., 1989, Hunger and public action, Clarendon Press, Oxford.

Fakuda-Parr, S., 2010, 'Global poverty and unequal development: Contemporary trends and issues', in W.A. Galston \& P.H. Hoffenberg (eds.), Poverty and morality: Religious perspectives, pp. 15-43, Cambridge University Press, New York.

Galston, W.A. \& Hoffenberg, P.H. (eds.), 2010, Poverty and morality: Religious and secular perspectives, Cambridge University Press, Cambridge.

Ganzevoort, R.R. \& Roeland, J.H., 2014, 'Lived religion: The praxis of practical theology', International Journal of Practical Theology 18(1), 91-101.

Graig, D. \& Porter, D., 2002, 'Poverty reduction strategy papers: A new convergence', World Development 31(1), 53-69. 
Harvard University, 2013, Curriculum vitae, Amartya Sen, viewed 19 October 2015 from http://scholar.harvard.edu/files/sen/files/cv_sen_amartya_jan2013_0.pdf

Harvard University, n.d., Amartya Sen: Biographical note, viewed 19 October 2015, from http://scholar.harvard.edu/sen/biocv

Hussain, I. \& Hanjra, M., 2004, 'Irrigation \& poverty alleviation', Irrigation \& Drainage $53,1-15$.

Klaasen, J.S., 2014, 'Practical theology: A critically engaged practical reason approach of practice, theory, practice and theory', HTS Teologiese Studies/Theological Studies 70(2), Art. 1950, 6 pages. http://dx.doi.org/10.4102/hts.v70i2.1950

Koopman, N., 2005, 'After ten years. Public theology in postapartheid South Africa: Lessons from a debate in the USA', Nederduitse Gereformeede Teologiese Tydskrif $46(1), 149-164$

Laderchi, C.R., Saith, R. \& Stewart, F., 2003, 'Does it matter that we do not agree on the definition of poverty? A comparison of four approaches', Oxford Development Studies 31(3), 243-274.

Laderchi, C.R., Saith, R. \& Stewart, F., 2006, 'Does the definition of poverty matter? Comparing four approaches', in International Poverty Centre (ed.), Poverty in focus: What is poverty?, pp. 10-11, viewed 03 February 2016, from http://www. ipc-undp.org/pub/IPCPovertylnFocus9.pdf

Millennium Development Goals, 2008, Official list of MDG indicators, viewed 19 Octobe 2015, from http://www1.eis.gov.bw/EIS/Shared\%20Documents/OfficialList2008.pd

Miller, S.M., Rein, M., Roby, P. \& Cross, B. 1967, 'Poverty, inequality and conflict', Annals of the American Academy of Political Science 373(1), 16-52.

Morrell, D., 2011, 'Who is poor?', Harvard Magazine, viewed 19 October 2015, from http://harvardmagazine.com/2011/01/who-is-poor

Patton, J., 1993, Pastoral care in context, Westminster/John Knox Press, Louisville.

Runciman, W.G., 1966, Relative deprivation and social justice, Routledge \& Kegan Paul, London.
Sen, A., 1960, Choice of technique, Basil Blackwell, Oxford.

Sen, A., 1975, Employment, technology and development, Clarendon Press, Oxford.

Sen, A., 1981, Poverty and famines: An essay on entitlement and deprivation, Clarendon Press, Oxford.

Sen, A., 1982, Utilitarianism and beyond, Cambridge University Press, Cambridge.

Sen, A., 1984, Resources, values and development, Blackwell, Oxford.

Sen, A., 1985, Commodities and capabilities, North-Holland, Amsterdam.

Sen, A., 1987, The standard of living, Cambridge University Press, Cambridge.

Sen, A., 1989, 'Development as capability expansion', Journal of Development Planning 19, 41-48.

Sen, A., 1999, Development as freedom, Oxford University Press, Oxford.

Sen, A. [1992] 2000, Inequality re-examined, Clarendon Press, Oxford.

Sen, A., 2009, The idea of justice, The Belknap Press of Harvard University Press, Cambridge.

Sen, A., 2011, Peace and democratic society, Open Book Publishers, Cambridge.

Sohlberg, P., 2006, 'Amartya Sen's entitlement approach: Empirical statement or conceptual framework?', International Journal of Social Welfare 15, 357-362.

Streeten, P., Burki, S.J., Haq, M.U., Hicks, M. \& Stewart F., 1982, First things first: Meeting basic human needs in developing countries, Oxford University Press, New York.

Sumner, A., 2007, 'Meaning versus measurement: Why do 'economic' indicators of poverty still predominate?', Development in Practice 17 (1), 4-13.

Townsend, P., 1971, The concept of poverty, Heinemann, London.

Wedderburn, D. (ed.), 1974, Poverty, inequality and class structure, University Press, Cambridge. 